\title{
Lactation response to soybean meal and rumen-protected methionine supplementation of corn silage-based diets ${ }^{1}$
}

\author{
H. Nursoy, ${ }^{*}$ M. Gonzalez Ronquillo,† A. P. Faciola, $\ddagger$ and G. A. Broderick $\S^{2,3}$ \\ *Department of Animal Nutrition, Veterinary Faculty, Bingol University, Bingol, Turkey 12000 \\ †Universidad Autonoma del Estado de Mexico, Facultad de Medicina Veterinaria y Zootecnia, Instituto Literario 100, Toluca, Mexico \\ ‡Department of Animal Sciences, University of Florida, Gainesville 32611 \\ §USDA-Agricultural Research Service, US Dairy Forage Research Center, 1925 Linden Drive, Madison, WI 53706
}

\begin{abstract}
Corn silage, an important forage fed to dairy cows in the United States, is energy rich but protein poor. The objectives of this experiment were to investigate the effects on production of milk and milk components of feeding corn silage-based diets with 4 levels of dietary crude protein $(\mathrm{CP})$ plus rumen-protected methionine (RPM). Thirty-six cows were blocked by days in milk into 9 squares and randomly assigned to 9 balanced $4 \times 4$ Latin squares with four 4 -wk periods. All diets were formulated to contain, as a percent of dry matter (DM), $50 \%$ corn silage, $10 \%$ alfalfa silage, $4 \%$ soyhulls, $2.4 \%$ mineral-vitamin supplement, and 30\% neutral detergent fiber. Supplemental RPM (Mepron, Evonik Corp., Kennesaw, GA) was added to all diets to maintain a Lys:Met ratio of 3.1 in digested AA. Ground high-moisture corn was reduced and soybean meal (SBM) plus RPM increased to give diets containing, on average, $11 \%$ CP (28\% corn, 31\% starch, $6 \%$ SBM, 4 g of RPM/d), $13 \%$ CP (23\% corn, $29 \%$ starch, $10 \%$ SBM, $8 \mathrm{~g}$ of RPM/d), $15 \%$ CP (19\% corn, $26 \%$ starch, $15 \%$ SBM, $10 \mathrm{~g}$ of RPM/d), and 17\% CP (14\% corn, $24 \%$ starch, 19\% SBM, $12 \mathrm{~g}$ of RPM/d). Data from the last $14 \mathrm{~d}$ of each period were analyzed using the mixed procedures in SAS (SAS Institute Inc., Cary, NC). With the exception of milk fat and milk lactose content, we found no significant effects of diet on all production traits. We did note linear responses to dietary $\mathrm{CP}$ concentration for intake, production of milk and milk components, and MUN. Cows fed the $11 \%$ CP diet had
\end{abstract}

\section{Received May 24, 2017.}

Accepted November 14, 2017.

${ }^{1}$ Mention of any trademark or proprietary product in this paper does not constitute a guarantee or warranty of the product by the USDA or the Agricultural Research Service and does not imply its approval to the exclusion of other products that also may be suitable.

${ }^{2}$ Retired; present address: Broderick Nutrition \& Research LLC, 221 Glen Hollow Road, Madison, WI 53705.

${ }^{3}$ Corresponding author: gbroderi@wisc.edu reduced DM intake, lost weight, and yielded less milk and milk components. Mean separation indicated that only true protein yield was lower on $13 \% \mathrm{CP}$ than on $17 \%$ dietary CP, but not different between 15 and $17 \%$ CP. This indicated no improvement in production of milk and milk components above $15 \%$ CP. Quadratic trends for yield of milk, energy-corrected milk, and true protein suggested that a dietary $\mathrm{CP}$ concentration greater than $15 \%$ may be necessary to maximize production or, alternately, that a plateau was reached and no further $\mathrm{CP}$ was required. Although diet influenced apparent digestibility of DM, organic matter, and neutral detergent fiber, digestibility did not increase linearly with dietary CP. However, we observed linear and quadratic effects of dietary $\mathrm{CP}$ on acid detergent fiber digestibility. As expected, we found a linear effect of dietary $\mathrm{CP}$ on apparent $\mathrm{N}$ digestibility and on fecal and urinary $\mathrm{N}$ excretion, but no effect of diet on estimated true $\mathrm{N}$ digestibility. Ruminal concentrations of ammonia, total AA, peptides, and branched-chain volatile fatty acids also increased linearly with dietary CP. Quadratic responses indicated that 14.0 to $14.8 \%$ $\mathrm{CP}$ was necessary to optimize digestion and energy utilization. Overall results indicated that, when RPM was added to increase Lys:Met to 3.1, $15 \% \mathrm{CP}$ was adequate for lactating dairy cows fed corn silage diets supplemented with SBM and secreting about $40 \mathrm{~kg}$ of milk/d; N excretion was lower than at $17 \% \mathrm{CP}$ but with no reduction in yield of milk and milk components.

Key words: corn silage, soybean meal, rumenprotected methionine, dietary crude protein

\section{INTRODUCTION}

Energy and protein in the diet must be properly matched to optimize milk production in dairy cows. Corn silage, an important forage fed to dairy cows in the United States, is rich in energy but low in CP. Solvent-extracted soybean meal (SBM), which is high in Lys but low in Met and the most common protein supplement fed to US dairy cows, is estimated to con- 
tain $43 \%$ RUP in its CP (DMI $=4$ times maintenance; NRC, 2001). Of the 3 protein concentrates tested by Brito et al. (2007), RUP flow measured using omasal sampling was greatest in cottonseed meal, intermediate in canola meal, and lowest in SBM; however, milk and protein yield were highest on canola meal, intermediate on SBM, and lowest on cottonseed meal. Milk and protein yield were greater on canola meal than on SBM (Huhtanen et al., 2011; Martineau et al., 2013); this difference was attributed partly to greater Met content in RUP supplied by canola meal (Broderick et al., 2015).

Conversion of feed $\mathrm{N}$ into milk $\mathrm{N}$ ranges from 23 to $34 \%$ in dairy cows with daily production of 30 to 50 $\mathrm{kg}$ of milk (Kalscheur et al., 2006; Arriola Apelo et al., 2014). Low N efficiency often makes it necessary to feed additional supplemental protein to improve yield of milk and milk components, further lowering efficiency and increasing cost of dairy production. Nitrogen not captured in milk is excreted in feces and especially in urine. Excreted urinary $\mathrm{N}$ is unstable, contributing to volatile losses of ammonia to the atmosphere and nitrate contamination of ground water, making dairy production less environmentally sustainable (Kaswari, 2004; Powell and Broderick, 2011). In addition, excessive dietary protein may also lead to increased incidence of health and reproductive problems (Jordan et al., 1983; Canfield et al., 1990). Increasing N efficiency in dairy cows without reducing yield is best achieved by reducing the total amount of $\mathrm{CP}$ fed to the animal and balancing the metabolizable AA supply (Lapierre et al., 2005; Brito and Broderick, 2007). Methionine is the EAA most often limiting in lactation diets based on legume and corn silages supplemented with SBM, and positive responses in milk and protein yields to rumenprotected Met (RPM) have been consistently observed (Patton, 2010; Zanton et al., 2014).

Previous work indicated that, on dairy diets based on SBM plus typical forages, about $16.5 \%$ CP appears to be adequate for mid-lactation cows (Broderick, 2003). Colmenero and Broderick (2006b) fed SBMsupplemented diets ranging from 13.5 to $19.4 \% \mathrm{CP}$ and found that milk and true protein yield were optimal at, respectively, 16.7 and $17.1 \%$ CP. Lowering dietary CP from 16.6 to $15.6 \%$ while replacing a portion of the solvent SBM with expeller SBM tended to reduce milk yield (Colmenero and Broderick, 2006a). Because Met is the first-limiting EAA in SBM CP, we hypothesized that supplementation of RPM rather than RUP would reduce the dietary $\mathrm{CP}$ content required to maintain secretion of milk and milk components. Therefore, the objective of our experiment was to determine the optimal CP concentration in lactation diets supplemented with SBM plus RPM.

\section{MATERIALS AND METHODS}

\section{Animals and Diets}

Thirty-six multiparous Holstein cows (8 fitted with permanent, 10-cm ruminal cannulas; Bar Diamond, Inc., Parma, ID) with mean (SD) parity $2.6(0.7), 623$ (54) $\mathrm{kg}$ of BW, 91 (37) DIM, and 48 (5) kg of milk/d at the start of the trial were blocked by DIM into nine $4 \times 4$ Latin squares ( 2 with ruminally cannulated cows) with four 4 -wk periods (total $16 \mathrm{wk}$ ). Cows were randomly assigned within squares to 1 of 4 balanced dietary treatment sequences. The 4 diets were fed as TMR for ad libitum intake and were formulated from corn silage, alfalfa silage, ground high-moisture and dry corn, SBM, soyhulls, minerals, and vitamins to contain $11,13,15$, and $17 \% \mathrm{CP}$ (DM basis). The 4 diets were supplemented with RPM (Mepron, Evonik Corp., Kennesaw, GA), which provided 4.2, 8.1, 10.3, and 12.4 $\mathrm{g} / \mathrm{d}$ of absorbed Met (assuming 85\% chemical DL-Met content with $72 \%$ bioavailability; Lee et al., 2012) in the diets containing, respectively, 11, 13, 15, and $17 \%$ CP. At the mean DMI observed on each dietary treatment, diets were estimated to provide 1,703 to 2,438 $\mathrm{g} / \mathrm{d}$ of MP with Lys:Met ratios of about 3.1 in the MP of each diet (NRC, 2001). To improve distribution of RPM in the TMR, 2 premixes were prepared containing (DM basis) only $98 \%$ ground shelled corn plus $2 \%$ molasses (control premix) or $91 \%$ ground shelled corn, $2 \%$ molasses, plus $7 \%$ of the RPM supplement (RPM premix); depending on batch size and treatment, 0 to $2.1 \mathrm{~kg} / \mathrm{batch}$ of control premix or 1.4 to $3.7 \mathrm{~kg} / \mathrm{batch}$ of RPM premix was weighed out to the nearest $0.05 \mathrm{~kg}$ on a top-loading balance before blending into specific batches of TMR. Mean compositions of the major feed ingredients fed during the trial are in Table 1. Compositions of experimental diets actually fed during the trial (based on daily as-fed weights and weekly mean DM contents of each ingredient mixed into the TMR) are in Table 2.

All cows of the experiment were injected with bST (500 mg of Posilac, Elanco Animal Health, Greenfield, IN) beginning on d 1 of the trial and at 14-d intervals throughout. Cows were housed in a tiestall barn and had ad libitum access to fresh water during the trial. Care and handling of the animals on the experiment were applied as outlined in the guidelines of the University of Wisconsin institutional animal care and use committee.

Each of the 4 experimental periods lasted $28 \mathrm{~d}$ and consisted of $14 \mathrm{~d}$ for adaptation after switching diets and $14 \mathrm{~d}$ for collection of intake and production data. Diets were offered once daily at $1000 \mathrm{~h}$ and orts were 
collected and weights recorded at $0900 \mathrm{~h}$. Feeding rate was adjusted daily to yield orts of about 5 to $10 \%$ of intake. Weekly composites of corn silage, alfalfa silage, and high-moisture shelled corn, plus the 4 different TMR and orts were obtained from daily subsamples of about $0.5 \mathrm{~kg}$ of each material and stored at $-20^{\circ} \mathrm{C}$. Weekly samples also were collected of SBM, soyhulls, and the 2 premixes and stored at room temperature. Dry matter was determined in weekly composites of corn silage, alfalfa silage, and high-moisture shelled corn by drying at $60^{\circ} \mathrm{C}$ for $48 \mathrm{~h}$ and in weekly samples of SBM, soyhulls, and the 2 premixes at $105^{\circ} \mathrm{C}$ (AOAC, 1980). These DM contents were used to make weekly adjustments of DM composition of TMR over the course of the trial. Intake of DM was computed based on $60^{\circ} \mathrm{C}$ DM determinations of weekly composites of TMR and orts. Dried $\left(60^{\circ} \mathrm{C}\right)$ samples of corn silage, alfalfa silage, and high-moisture shelled corn and undried samples of SBM, soyhulls, and the 2 premixes from wk 3 and 4 of each period (8 samples of each ingredient over the trial) were ground to pass a 1-mm screen (Wiley mill, Arthur H. Thomas, Philadelphia, PA). These were analyzed for total N (Leco FP-2000 N Analyzer, Leco Instruments, Inc., St. Joseph, MI), DM at $105^{\circ} \mathrm{C}$, ash and $\mathrm{OM}$ (AOAC, 1980), sequentially for NDF, ADF and ADIN using heat-stable $\alpha$-amylase and $\mathrm{Na}_{2} \mathrm{SO}_{3}$ (Van Soest et al., 1991; Hintz et al., 1996), and for NDIN omitting $\alpha$-amylase and $\mathrm{Na}_{2} \mathrm{SO}_{3}$ during extraction (Licitra et al., 1996). The 8 samples each of frozen composites of alfalfa and corn silages were thawed, extracted, and analyzed for pH, ammonia, and NPN (Leco FP-2000 N Analyzer) as described by Muck (1987). The 32 TMR samples from wk 3 and 4 of each period were analyzed for total lipid according to AOAC International (1997; method 920.39; Dairyland Laboratories, Arcadia, WI). The 16 TMR samples collected during wk 4 of each period also were analyzed for indigestible ADF (ADF remaining after $288 \mathrm{~h}$ of in situ incubation) by the method of Huhtanen et al. (1994).

Cows were milked twice daily at 0500 and $1700 \mathrm{~h}$ and milk yield was recorded at each milking in all experimental periods. Milk samples from a.m. and p.m. milkings were collected on d 17 to 18 and 24 to 25 of each period and analyzed for fat, true protein, lactose, SNF, and MUN by infrared analysis (AgSource, Verona, WI) with a Foss FT6000 (Foss North America Inc., Eden Prairie, MN) using AOAC (1990) method no. 972.16. Concentrations and yields of fat, true protein, lactose and SNF, and MUN concentration were computed as weighted means based on a.m. and p.m. milk yields on each test day. Yields of ECM also were computed as described by Krause and Combs (2003). Efficiency of conversion of feed DM was calculated for each cow over the last 2 wk of each period by dividing mean yield of actual milk and ECM by mean DMI. Apparent $\mathrm{N}$ efficiency (assuming no retention or mobilization of body $\mathrm{N}$ ) was also computed for each cow by dividing the period mean for milk $\mathrm{N}$ secretion (milk true protein/6.38) by mean $\mathrm{N}$ intake. For computation of BW change, BW of all cows was measured on 3 consecutive days just before beginning the experiment and at the end of each period.

On d 28 of each period, spot urine and fecal samples were collected $6 \mathrm{~h}$ before and $6 \mathrm{~h}$ after feeding. Urine was immediately diluted by mixing $15 \mathrm{~mL}$ of sample with $60 \mathrm{~mL}$ of $0.072 \mathrm{~N} \mathrm{H}_{2} \mathrm{SO}_{4}$ and storing at $-20^{\circ} \mathrm{C}$

Table 1. Composition of principal dietary ingredients

\begin{tabular}{|c|c|c|c|c|c|c|c|c|}
\hline \multirow[b]{2}{*}{ Component } & \multicolumn{2}{|c|}{ Corn silage } & \multicolumn{2}{|c|}{ Alfalfa silage } & \multicolumn{2}{|c|}{$\mathrm{HMSC}^{1}$} & \multicolumn{2}{|c|}{ Soybean meal } \\
\hline & Mean $^{2}$ & SEM & Mean & SEM & Mean & SEM & Mean & SEM \\
\hline DM, \% as fed & 39.1 & 1.69 & 39.3 & 2.24 & 84.0 & 1.57 & 89.5 & 0.17 \\
\hline $\mathrm{CP}, \%$ of $\mathrm{DM}$ & 6.1 & 0.38 & 20.9 & 0.31 & 7.7 & 0.22 & 52.6 & 0.63 \\
\hline Ash, $\%$ of DM & 4.2 & 0.09 & 9.8 & 0.28 & 1.4 & 0.06 & 7.5 & 0.16 \\
\hline $\mathrm{OM}, \%$ of $\mathrm{DM}$ & 95.8 & 0.09 & 90.2 & 0.28 & 98.6 & 0.06 & 92.5 & 0.16 \\
\hline $\mathrm{NDF}, \%$ of $\mathrm{DM}$ & 40.9 & 1.49 & 42.4 & 0.66 & 8.8 & 0.23 & 9.8 & 0.60 \\
\hline $\mathrm{ADF}, \%$ of DM & 20.5 & 0.68 & 31.8 & 0.73 & 1.8 & 0.06 & 5.2 & 0.31 \\
\hline $\mathrm{NFC},{ }^{3} \%$ of $\mathrm{DM}$ & 49.7 & 1.35 & 29.4 & 0.77 & 83.1 & 0.42 & 31.7 & 0.64 \\
\hline NDIN, \% of total $\mathrm{N}$ & 14.2 & 0.70 & 11.6 & 0.71 & 13.3 & 0.84 & 3.0 & 0.16 \\
\hline ADIN, $\%$ of total N & 1.6 & 0.16 & 4.0 & 0.17 & 0.0 & 0.25 & 0.0 & 0.02 \\
\hline Fraction $\mathrm{B} 2,{ }^{4} \%$ of total $\mathrm{N}$ & 12.7 & 0.57 & 8.4 & 0.91 & 13.3 & 0.73 & 2.9 & 0.15 \\
\hline NPN. $\%$ of total N & 49.5 & 4.7 & 52.5 & 8.0 & - & - & - & - \\
\hline Ammonia- $\mathrm{N}, \%$ of total $\mathrm{N}$ & 1.9 & 0.2 & 4.4 & 0.8 & - & - & - & - \\
\hline $\mathrm{pH}$ & 4.06 & 0.04 & 4.46 & 0.55 & - & - & - & - \\
\hline
\end{tabular}

${ }^{1} \mathrm{HMSC}=$ high-moisture shelled corn.

${ }^{2}$ Means from 8 replicate samples of each feed ingredient.

${ }^{3}$ Nonfiber carbohydrates computed according to NRC (2001) model.

${ }^{4}$ Fraction B2 = NDIN - ADIN (Higgs et al., 2015). 
Table 2. Composition of diets ranging from 11 to $17 \% \mathrm{CP}$

\begin{tabular}{|c|c|c|c|c|}
\hline \multirow[b]{2}{*}{ Item } & \multicolumn{4}{|c|}{ Dietary CP, $\%$ of DM } \\
\hline & 11 & 13 & 15 & 17 \\
\hline \multicolumn{5}{|l|}{ Ingredient, $\%$ of $\mathrm{DM}$} \\
\hline Corn silage & 50.5 & 50.5 & 50.5 & 50.5 \\
\hline Alfalfa silage & 10.4 & 10.4 & 10.4 & 10.4 \\
\hline High-moisture shelled corn & 26.0 & 21.5 & 17.1 & 12.8 \\
\hline Ground shelled corn & 1.01 & 1.03 & 1.05 & 1.06 \\
\hline Soybean meal & 5.6 & 10.0 & 14.3 & 18.5 \\
\hline Soy hulls & 4.0 & 4.0 & 4.0 & 4.0 \\
\hline Molasses & 0.02 & 0.02 & 0.02 & 0.02 \\
\hline RPM product $^{1}$ & 0.029 & 0.052 & 0.067 & 0.079 \\
\hline Calcium sulfate & 1.37 & 1.38 & 1.38 & 1.38 \\
\hline Biophos $^{2}$ & 0.22 & 0.22 & 0.22 & 0.22 \\
\hline Sodium chloride & 0.18 & 0.18 & 0.18 & 0.18 \\
\hline Magnesium oxide/sulfate & 0.51 & 0.51 & 0.51 & 0.51 \\
\hline Vitamins-trace minerals $^{3}$ & 0.13 & 0.13 & 0.13 & 0.13 \\
\hline \multicolumn{5}{|l|}{ Composition } \\
\hline $\mathrm{CP}, \%$ of $\mathrm{DM}$ & 10.9 & 12.9 & 14.8 & 16.8 \\
\hline Soybean meal CP, $\%$ of total CP & 27 & 41 & 51 & 58 \\
\hline Ash, $\%$ of DM & 4.2 & 4.4 & 4.7 & 4.9 \\
\hline $\mathrm{NDF}, \%$ of DM & 30.3 & 30.4 & 30.5 & 30.5 \\
\hline $\mathrm{ADF}, \%$ of $\mathrm{DM}$ & 16.1 & 16.3 & 16.4 & 16.6 \\
\hline NDIN, $\%$ of total $\mathrm{N}$ & 11.2 & 9.7 & 8.6 & 7.7 \\
\hline ADIN, $\%$ of total $\mathrm{N}$ & 1.6 & 1.3 & 1.1 & 1.0 \\
\hline Fraction $\mathrm{B} 2,{ }^{4} \%$ of total $\mathrm{N}$ & 9.7 & 8.4 & 7.4 & 6.7 \\
\hline Ether extract, \% of DM & 3.2 & 3.1 & 3.0 & 2.9 \\
\hline Starch ${ }^{5} \%$ of DM & 30.6 & 28.5 & 26.4 & 24.4 \\
\hline $\mathrm{NFC}^{6} \%$ of DM & 49.8 & 47.7 & 45.7 & 43.8 \\
\hline $\mathrm{NE}_{\mathrm{L}}{ }^{6}{ }^{6} \mathrm{Mcal} / \mathrm{kg}$ of $\mathrm{DM}$ & 1.50 & 1.52 & 1.53 & 1.55 \\
\hline $\mathrm{MP}^{6,7} \mathrm{~g} / \mathrm{d}$ & 1,703 & 2,122 & 2,294 & 2,438 \\
\hline NRC-predicted ECM,${ }^{6,7} \mathrm{~kg} / \mathrm{d}$ & 34 & 37 & 37 & 38 \\
\hline NRC-predicted true protein, ${ }^{6,7} \mathrm{~kg} / \mathrm{d}$ & 0.55 & 0.81 & 0.94 & 1.03 \\
\hline NorFor-predicted ECM ${ }^{8} \mathrm{~kg} / \mathrm{d}$ & 35 & 38 & 38 & 39 \\
\hline NorFor-predicted true protein. ${ }^{8} \mathrm{~kg} / \mathrm{d}$ & 1.10 & 1.21 & 1.21 & 1.25 \\
\hline Lys in $\mathrm{MP}^{6,7} \mathrm{~g} / \mathrm{d}$ & 111 & 142 & 155 & 163 \\
\hline Met in $M P, 6,7 \mathrm{~g} / \mathrm{d}$ & 32 & 38 & 40 & 41 \\
\hline RPM (Mepron), ${ }^{7} \mathrm{~g} / \mathrm{d}$ & 4.2 & 8.1 & 10.3 & 12.4 \\
\hline Total Met supply, ${ }^{6}, \mathrm{~g} / \mathrm{d}$ & 36 & 46 & 50 & 53 \\
\hline Lys in $M P, 6,7 \%$ & 6.4 & 6.7 & 6.8 & 6.8 \\
\hline Met in MP, ${ }^{6,7} \%$ & 2.1 & 2.2 & 2.2 & 2.2 \\
\hline Lys:Met ratio (without RPM) & 3.5 & 3.7 & 3.9 & 4.0 \\
\hline Lys:Met ratio (total) $)^{6,7}$ & 3.1 & 3.1 & 3.1 & 3.1 \\
\hline
\end{tabular}

${ }^{1}$ Rumen-protected Met fed as Mepron, Degussa Corp., Kennesaw, GA.

${ }^{2}$ Biophos obtained from Mosaic Global Sales, Lithia, FL.

${ }^{3}$ Provided (per kilogram of DM): $56 \mathrm{mg}$ of $\mathrm{Zn}, 46 \mathrm{mg}$ of $\mathrm{Mn}, 22 \mathrm{mg}$ of Fe, $12 \mathrm{mg}$ of $\mathrm{Cu}, 0.9 \mathrm{mg}$ of I, $0.4 \mathrm{mg}$ of $\mathrm{Co}, 0.3 \mathrm{mg}$ of Se, 6,440 IU of vitamin A, 2,000 IU of vitamin D, and $16 \mathrm{IU}$ of vitamin $\mathrm{E}$; and $12 \mathrm{mg}$ Monensin. ${ }^{4}$ Fraction B2 = NDIN - ADIN (Higgs et al., 2015).

${ }^{5}$ Starch computations based on Table 4-2 of NRC (2001).

${ }^{6}$ Computed according to NRC (2001) model at mean DMI observed on each diet (Table 3). ECM yield computed based on NRC (2001) estimates of fat, true protein, and lactose yields using the equation of Krause and Combs (2003).

${ }^{7}$ Computed assuming rumen-protected Met (RPM) product contained $85 \%$ Met with $72 \%$ bioavailability (Lee et al., 2012) at mean DMI observed for each dietary treatment.

${ }^{8}$ Computed according to NorFor (2011) model. ECM computed using the factor 4.184 MJ/Mcal and assuming $0.951 \mathrm{~kg}$ of milk true protein $/ \mathrm{kg}$ of total milk protein (Cerbulis and Farrell, 1975).

until analysis. Fecal samples were dried for $72 \mathrm{~h}$ at $60^{\circ} \mathrm{C}$, ground through a $1-\mathrm{mm}$ screen (Wiley mill), and composited on an equal DM basis to obtain 1 fecal sample/cow per period. All fecal samples were analyzed for $\mathrm{DM}$, ash, OM, NDF, ADF, total N, and indigest- ible ADF using the assays described above for feeds. Indigestible ADF was used as an internal marker to estimate apparent nutrient digestibility and fecal output (Cochran et al., 1986). Excretion of metabolic fecal N (MFN), estimated as $4.8 \mathrm{~g} / \mathrm{kg}$ of DMI (NRC, 
2001), was used to compute true $\mathrm{N}$ digestibility from apparent $\mathrm{N}$ digestibility for each diet. Urine samples were thawed and analyzed for total $\mathrm{N}$ by elemental analysis (Leco FP-2000 N Analyzer), for urea using an automated colorimetric assay (Broderick and Clayton, 1997) adapted to flow-injection (Lachat Quick-Chem 8000 FIA, Lachat Instruments, Loveland, CO), and for creatinine (Valadares et al., 1999). Daily urine volume and excretion of urea $\mathrm{N}$ were estimated from mean urinary concentrations in each period and assuming a creatinine excretion rate of $29 \mathrm{mg} / \mathrm{kg}$ of BW (Valadares et al., 1999).

On d 27 to 28 of each period, about 100 to $200 \mathrm{~mL}$ of fluid digesta was collected from 4 locations in the ventral rumen at 0 (just before feeding), 1, 2, 4, 6, 8, 12,18 , and $24 \mathrm{~h}$ after feeding in the 8 lactating Holstein cows fitted with ruminal cannulas using the probe described by Colmenero and Broderick (2006a). At each sampling, mixed fluid digesta was strained through 2 layers of cheesecloth and $\mathrm{pH}$ was measured immediately in strained fluid using a glass electrode. Two 10-mL aliquots of ruminal fluid were then preserved in scintillation vials by addition of $0.2 \mathrm{~mL}$ of $50 \% \mathrm{H}_{2} \mathrm{SO}_{4}$ and stored at $-20^{\circ} \mathrm{C}$; the remaining fluid and digesta were returned to the rumen. Just before analysis, samples were thawed and centrifuged $(15,300 \times g$ for $20 \mathrm{~min}$ at $4^{\circ} \mathrm{C}$ ) and flow-injection analyses (Lachat QuikChem 8000) applied to supernatants to determine ammonia using a phenol-hypochlorite method (Lachat Method 18-107-06-1-A). Supernatants were also analyzed using the o-phthaldialdehyde reaction (Roth, 1971) for total AA by fluorescence and for total AA plus oligopeptide concentrations by absorbance (Colombini et al., 2011). Leucine was the standard in both o-phthaldialdehyde assays and total AA and total AA plus oligopeptides are reported as Leu equivalents. The other ruminal samples were thawed and centrifuged $(28,000 \times g$ for $30 \mathrm{~min}$ at $4^{\circ} \mathrm{C}$ ) before VFA determination using the method described by Broderick et al. (2015). This method did not resolve isovalerate and 2-methyl butyrate. Timeweighted means were computed for all ruminal traits ( $\mathrm{pH}$ and concentrations of ammonia, total free $\mathrm{AA}$, and individual and total VFA) using the equation

$$
\begin{aligned}
& \text { Time-weighted mean }=[\operatorname{avg}(0-1 \mathrm{~h})+\operatorname{avg}(1-2 \mathrm{~h}) \\
& +2 \times \operatorname{avg}(2-4 \mathrm{~h})+2 \times \operatorname{avg}(4-6 \mathrm{~h})+2 \\
& \times \operatorname{avg}(6-8 \mathrm{~h})+4 \times \operatorname{avg}(8-12 \mathrm{~h})+6 \\
& \times \operatorname{avg}(12-18 \mathrm{~h})+6 \times \operatorname{avg}(18-24 \mathrm{~h})] / 24,
\end{aligned}
$$

where $\operatorname{avg}(n-n \mathrm{~h})$ represent the mean value for each ruminal trait observed at the sampling times listed above.

\section{Statistical Analysis}

A single mean observation was computed for all production data for each cow over the last 2 wk of each period; single time-weighted means were computed for all ruminal traits measured in cannulated cows. Data were analyzed as replicated $4 \times 4$ Latin squares using the mixed procedures of SAS Institute Inc. (2013). Model sums of squares from the data were separated into overall mean, cow(within square), square, period, diet (dietary CP concentration), and overall error. All variables were considered fixed except cow(within square) and overall error, which were considered random. The PDIFF option was used to test for treatment differences among least squares means. Orthogonal contrasts were used to test for linear and quadratic effects of dietary CP concentration. Least squares means are reported for all statistical analyses; significance was declared at $P \leq 0.05$ and trends at $0.05<P \leq 0.10$.

\section{RESULTS AND DISCUSSION}

\section{Feed Quality and Diet Composition}

Composition data on the major feed ingredients used to prepare the TMR fed in the trial are in Table 1. Contents of DM, CP, NDF, and ADF in alfalfa and corn silages and high-moisture corn indicated that these feedstuffs were of typical composition (NRC, 2001). The NPN in alfalfa silage represented $53 \%$ of total N; NPN normally accounts for 45 to $55 \%$ of total $\mathrm{N}$ in alfalfa silage (Broderick, 1995). Very low contents of ammonia- $\mathrm{N}$ in both alfalfa and corn silages indicated these feeds were well preserved (McDonald et al., 1991). Concentrations of ADIN in the 2 silages also were low and, on average, no ADIN was detected in the highmoisture corn and SBM, indicating essentially no heat damage to the major feed ingredients fed in this study.

Composition of the 4 diets fed in the study is in Table 2. Soybean meal, which was added at the expense of high-moisture corn, increased from about 6 to $19 \%$ of dietary DM; actual CP concentrations ranged from 10.9 to $16.8 \%$ (DM basis). Dietary alterations had little effect on NDF, ADF, and ADIN content; however, NDIN and $\mathrm{N}$ fraction B2 (NDIN - ADIN) as a proportion of total CP, as well as starch and NFC (as a proportion of DM), declined as SBM increased. Based on the NRC (2001) model, yield of ECM and milk true protein was predicted to increase by, respectively, 4 and 0.48 $\mathrm{kg} / \mathrm{d}$ because estimated MP supply increased $735 \mathrm{~g} / \mathrm{d}$ between the 11 and $17 \%$ CP diets (Table 2). However, the NRC (2001) model underestimated ECM yield by only 1 to $2 \mathrm{~kg} / \mathrm{d}$, but true protein yield by 0.53 to 
$0.27 \mathrm{~kg} / \mathrm{d}$ as CP increased from 11 to $17 \%$ (Table 3 ). Yield predictions made using the NorFor (2011) model ranged from 33 to $39 \mathrm{~kg}$ of $\mathrm{ECM} / \mathrm{d}$ and 1.10 to 1.25 $\mathrm{kg}$ of true protein/d (Table 2); the estimates of milk true protein averaged $99 \%$ of observed yields (Table 3). NorFor (2011) applies variable MP efficiencies that decline with increasing MP supply rather than a constant $67 \%$ MP efficiency as is used in NRC (2001). Neither model currently considers EAA pattern when estimating ECM and protein yield. Without RPM supplementation, Lys:Met ratios ranged from 3.5 to 4.0 on diets supplemented with SBM, implicating Met as the first-limiting AA in MP (NRC, 2001). Assuming 72\% bioavailability of Met in the RPM source (Lee et al., 2012), RPM supplementation improved Lys:Met ratio to approximately 3.1 in all 4 diets. However, estimated Met and Lys concentrations in MP were not constant across diets (Table 2); Met and Lys increased from 2.1 and $6.4 \%$ of MP (on $11 \% \mathrm{CP}$ ) to 2.2 and $6.8 \%$ of MP (on 15 and $17 \%$ CP). Although NRC (2001) estimated Lys requirements when Met was about $2.0 \%$ of MP and estimated Met requirements when Lys was about 6.5\% of MP, optimal Met and Lys concentrations were set equal to, respectively, 2.4 and $7.2 \%$ of MP. Schwab et al. (2003), however, suggested that Met and Lys were adequate in practical diets at 2.2 and $6.8 \%$ of MP.

\section{Production Responses}

The RUP in SBM is first-limiting in Met and several trials have shown that RPM supplementation of SBM-containing diets increases milk concentrations of total protein (Armentano et al., 1997; Berthiaume et al., 2006), true protein (Berthiaume et al., 2006), and casein (Overton et al., 1998). Moreover, RPM supplementation elevated yield of milk (Schmidt et al., 1999), total protein (Armentano et al., 1997; Zanton et al., 2014), and true protein (Rulquin and Delaby, 1997; Patton, 2010). Therefore, we hypothesized that RPM supplementation would lower the dietary $\mathrm{CP}$ concentration needed to maintain production of milk and milk components. Lactation performance results are reported in Table 3. Except for milk fat and lactose concentrations, treatment and linear effects $(P \leq$ $0.05)$ were observed for all production traits measured in our study. Quadratic effects were also detected for BW change and for MUN concentration and quadratic trends were detected for DMI, BW change, and for yield of milk, ECM, and true protein. Colmenero and Broderick (2006b) found yields of milk and milk true protein were maximal at, respectively, 16.7 and $17.1 \% \mathrm{CP}$ when feeding diets composed of similar ingredients but with greater amounts of alfalfa silage and lower amounts of corn silage. The highly significant linear responses observed for most production traits were not surprising given the range of $\mathrm{CP}$ concentrations fed in our study. Although the quadratic responses will be discussed later, these strong linear responses suggested that mean separation should be applied to production traits to identify dietary $\mathrm{CP}$ concentrations above which there were no further improvements. Using this approach, production on $11 \% \mathrm{CP}$ was clearly lower than on 13 to $17 \% \mathrm{CP}$; this was at least partly explained by DMI being $1.7 \mathrm{~kg} / \mathrm{d}$ less than on the average of the other 3

Table 3. Production of lactating cows fed diets with increasing CP content but with constant estimated Lys:Met ratio of 3.1

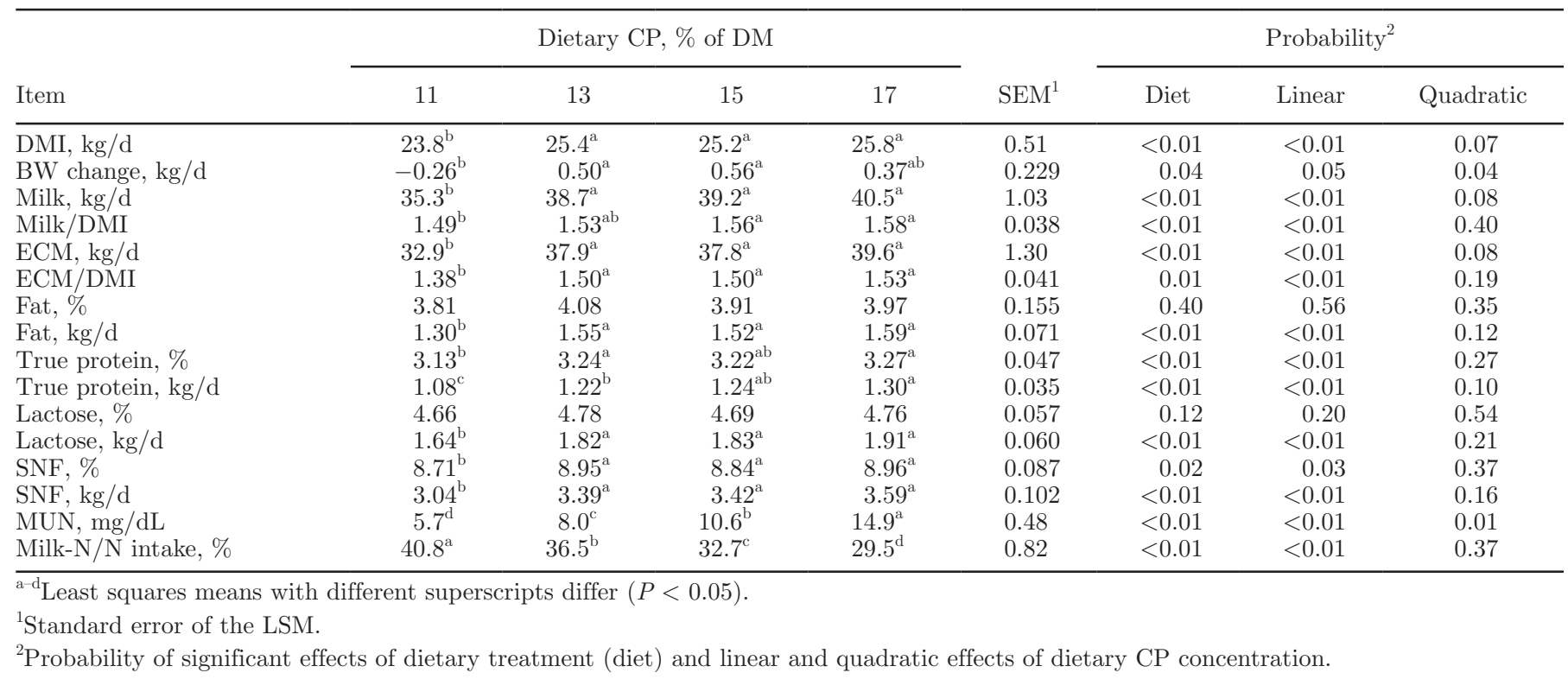


diets. Interestingly, only true protein yield on $13 \% \mathrm{CP}$ was lower than on the $17 \% \mathrm{CP}$ diet. For no production trait was yield of milk, ECM and milk components, or milk composition different between diets containing 15 and $17 \% \mathrm{CP}$ when supplemented with RPM. Colmenero and Broderick (2006a) reported that milk yield tended to be lower when CP was reduced from 16.6 to $15.6 \% \mathrm{CP}$, despite supplementation of RUP from expeller soybean meal on the lower CP diet. Swanepoel et al. (2015) reported that RPM supplementation increased milk yield and fat and protein concentration, but reduced milk lactose content and yield in Holstein cows fed $17 \%$ canola meal rations.

Linear responses of increasing MUN and decreasing apparent $\mathrm{N}$ efficiency $(P<0.01)$ with increasing dietary CP were anticipated. Milk urea concentration, which is an indicator of $\mathrm{N}$ inefficiency (Broderick and Clayton, 1997; Nousiainen et al., 2004), increased with each increment of dietary CP. Apparent N efficiency was more than 3 percentage units greater on 15 than on $17 \%$ dietary $\mathrm{CP}$ in our trial. The equation obtained by Nousiainen et al. (2004) by regressing MUN on dietary CP accurately predicted the MUN concentrations observed in the current study; the mean difference between observed and predicted values was less than $0.1 \mathrm{mg} / \mathrm{dL}$.

\section{Nutrient Digestibility and N Excretion}

Nutrient digestibility and fecal and urinary $\mathrm{N}$ excretion, estimated using internal markers, are reported in Table 4. In our study, apparent digestibility of DM and $\mathrm{OM}$ and total-tract digestibility of NDF and ADF were affected by dietary treatment, with greatest digestibility for all 4 nutrients occurring at 13\% CP. Linear effects of dietary CP content were found for ADF and apparent $\mathrm{N}$ digestibility, and quadratic effects on $\mathrm{OM}$ and ADF were also detected. The quadratic responses are discussed below. The BW loss on the $11 \% \mathrm{CP}$ diet (Table 3) was surprising because intake of digested OM was $16.3 \mathrm{~kg} / \mathrm{d}$ versus an average of $17.7 \mathrm{~kg} / \mathrm{d}$ on the other 3 diets, which was only $9 \%$ lower than on 13 to $17 \%$ CP. Cows were in mid lactation during the trial and should have been gaining weight to replace the BW and BCS loss occurring in early lactation; hence, the weight loss observed on the $11 \% \mathrm{CP}$ diet would not be sustainable. A possible explanation is that an inadequate MP supply may have impaired energy utilization on that diet. Effective dietary $\mathrm{NE}_{\mathrm{L}}$ value was computed from milk ECM yield (assuming $0.749 \mathrm{Mcal} /$ kg; Krause and Combs, 2003), plus BW change (6.98 Mcal $/ \mathrm{kg}$ change in EBW; NRC, 2001) and maintenance (0.080 Mcal $/ \mathrm{kg}$ of $\mathrm{BW}^{0.75}$ (metabolic BW) at mean BW of $640 \mathrm{~kg}$; NRC, 2001), was $1.40 \mathrm{Mcal} / \mathrm{kg}$ of DM for the $11 \% \mathrm{CP}$ diet versus an average $1.65 \mathrm{Mcal} / \mathrm{kg}$ of $\mathrm{DM}$ for the other 3 diets, which was $28 \%$ greater. Several literature reports document that improved MP status improved energy utilization; Brun-Lafleur et al. (2010) observed a linear increase in milk and fat yield as MP supply increased in diets formulated to be adequate and equal in energy supply. Auldist et al. (2014) reported that replacing starchy concentrates with canola meal in supplements fed to grazing dairy cows increased ECM yield.

As anticipated, apparent $\mathrm{N}$ digestibility increased linearly with increasing CP content of the diet (Table 4). This typically occurs because of dilution of MFN with elevated dietary CP (Nousiainen et al., 2009). We estimated true $\mathrm{N}$ digestibility by computing MFN as equivalent to $4.8 \mathrm{~g}$ of $\mathrm{N} / \mathrm{kg}$ of DMI (NRC, 2001). Correcting observed fecal $\mathrm{N}$ excretion for this amount of MFN yielded true digestibility estimates ranging from 84 to $86 \%$, which were not different among diets ( $P$ $=0.34)$. True $\mathrm{N}$ digestibility estimated from the data of Colmenero and Broderick (2006b) averaged 85.5\%. Although NDF digestibility was influenced by diet no linear or quadratic effects were detected; NDF digestibility was greater on $13 \% \mathrm{CP}$ than on the other 3 diets. Overall mean digestibility for NDF was $41 \%$ and for ADF was 44\%. Chen et al. (2011) reported a mean NDF digestibility of $50 \%$ for cows consuming $25 \mathrm{~kg}$ of $\mathrm{DM} / \mathrm{d}$ of a $60 \%$ forage diet, but with a $35: 25 \mathrm{DM}$ ratio of corn silage:alfalfa silage. Moreover, Faciola and Broderick (2014) observed NDF and ADF digestibilities of 44 and $49 \%$, respectively, when cows were fed the control diet (i.e., with no added lipid) with a 10:50 ratio of corn silage:alfalfa silage DM. Although Lopes et al. (2015) found greater indigestible NDF in alfalfa silage versus corn silage, apparent total-tract NDF digestibility increased as the dietary proportion of alfalfa silage increased. This result was explained by a rate of ruminal digestion of digestible NDF in alfalfa silage that was twice as rapid as that for corn silage. This suggests that the relatively low fiber digestion observed in the current trial was due in part to the low level of alfalfa silage in the diet.

Urine volume ranged from 39 to $47 \mathrm{~L} / \mathrm{d}$ and increased linearly with increasing dietary $\mathrm{CP}$ concentration (Table 4). Urine volume is influenced by both mineral and dietary CP intake. Valadares et al. (1999) reported that urine volume increased from 32 to $48 \mathrm{~L} / \mathrm{d}$ as dietary alfalfa silage increased from 35 to $80 \%$ of dietary DM; alfalfa forage from first and second cutting was reported to average $3.5 \%$ potassium on a DM basis (Kume et al., 2001). Eriksson and Rustas (2014) observed urine volumes ranging from 14 to $40 \mathrm{~L} / \mathrm{d}$ as potassium intake 
Table 4. Apparent total-tract digestibility, true $\mathrm{N}$ digestibility, and $\mathrm{N}$ metabolism in lactating cows fed diets with increasing $\mathrm{CP}$ content but with constant estimated Lys:Met ratio of 3.1

\begin{tabular}{|c|c|c|c|c|c|c|c|c|}
\hline \multirow[b]{2}{*}{ Item } & \multicolumn{4}{|c|}{ Dietary CP, \% of DM } & \multirow[b]{2}{*}{$\mathrm{SEM}^{1}$} & \multicolumn{3}{|c|}{ Probability $^{2}$} \\
\hline & 11 & 13 & 15 & 17 & & Diet & Linear & Quadratic \\
\hline \multicolumn{9}{|l|}{ Apparent digestibility, $\%$} \\
\hline DM & $67.0^{\mathrm{b}}$ & $68.9^{\mathrm{a}}$ & $66.9^{\mathrm{b}}$ & $67.3^{\mathrm{b}}$ & 0.51 & 0.01 & 0.67 & 0.12 \\
\hline $\mathrm{OM}$ & $68.4^{\mathrm{b}}$ & $70.6^{\mathrm{a}}$ & $68.7^{\mathrm{b}}$ & $69.1^{\mathrm{b}}$ & 0.49 & 0.01 & 0.96 & 0.05 \\
\hline Nitrogen & $57.0^{\mathrm{c}}$ & $62.9^{\mathrm{b}}$ & $64.0^{\mathrm{b}}$ & $67.8^{\mathrm{a}}$ & 0.93 & $<0.01$ & $<0.01$ & 0.20 \\
\hline True $\mathrm{N}$ digestibility $^{3}$ & 84.5 & 86.1 & 84.3 & 85.7 & 0.94 & 0.34 & 0.63 & 0.89 \\
\hline \multicolumn{9}{|l|}{$\mathrm{N}$ metabolism } \\
\hline $\mathrm{N}$ intake, $\mathrm{g} / \mathrm{d}$ & $414^{\mathrm{d}}$ & $524^{\mathrm{c}}$ & $597^{\mathrm{b}}$ & $691^{\mathrm{a}}$ & 11.3 & $<0.01$ & $<0.01$ & 0.24 \\
\hline Fecal N, g/d & $180^{\mathrm{c}}$ & $195^{\mathrm{b}}$ & $214^{\mathrm{ab}}$ & $222^{\mathrm{a}}$ & 7.0 & $<0.01$ & $<0.01$ & 0.49 \\
\hline Fecal N/N intake, $\%$ & $43.0^{\mathrm{a}}$ & $37.1^{\mathrm{b}}$ & $36.0^{\mathrm{b}}$ & $32.2^{\mathrm{c}}$ & 0.93 & $<0.01$ & $<0.01$ & 0.20 \\
\hline Urine volume, $\mathrm{L} / \mathrm{d}$ & $38.5^{\mathrm{b}}$ & $40.7^{\mathrm{b}}$ & $45.0^{\mathrm{a}}$ & $47.3^{\mathrm{a}}$ & 1.74 & $<0.01$ & $<0.01$ & 0.96 \\
\hline Urinary urea $\mathrm{N}, \mathrm{g} / \mathrm{d}$ & $24.3^{\mathrm{d}}$ & $66.9^{\mathrm{c}}$ & $106^{\mathrm{b}}$ & $176^{\mathrm{a}}$ & 7.5 & $<0.01$ & $<0.01$ & 0.03 \\
\hline Urinary urea N/TUN, ${ }^{4} \%$ & $31.2^{\mathrm{c}}$ & $50.0^{\mathrm{b}}$ & $56.0^{\mathrm{b}}$ & $75.5^{\mathrm{a}}$ & 3.07 & $<0.01$ & $<0.01$ & 0.89 \\
\hline
\end{tabular}

${ }^{\mathrm{a}-\mathrm{d}}$ Least squares means with different superscripts differ $(P<0.05)$.

${ }^{1}$ Standard error of the LSM.

${ }^{2}$ Probability of significant effects of dietary treatment (diet) and linear and quadratic effects of dietary CP concentration.

${ }^{3}$ True $\mathrm{N}$ digestibility computed assuming metabolic fecal $\mathrm{n}=4.8 \mathrm{~g} / \mathrm{kg}$ of DMI (NRC, 2001).

${ }^{4} \mathrm{TUN}=$ total urinary $\mathrm{N}$.

increased from 240 to $686 \mathrm{~g} / \mathrm{d}$; sodium intake has an effect on urine volume similar to potassium intake (Dijkstra et al., 2013b). Moreover, Dijkstra et al. (2013b) summarized data indicating that increasing ruminal balance of RDP from 0.1 to $1.0 \mathrm{~kg} / \mathrm{d}$ increased urine volume from 32 to $51 \mathrm{~L} / \mathrm{d}$ at approximately equal sodium and N intakes. Furthermore, Kume et al. (2008) observed a strong correlation between urine volume and urinary $\mathrm{N}$ excretion. Amounts of fecal and urinary $\mathrm{N}$ excretion also increased linearly with dietary CP but, as expected, fecal and urinary $\mathrm{N}$ excretion had different patterns when expressed as proportions of $\mathrm{N}$ intake; fecal $\mathrm{N}$ declined from 43 to $32 \%$ of $\mathrm{N}$ intake whereas urinary $\mathrm{N}$ increased from 21 to $35 \%$ of $\mathrm{N}$ intake over the range of $\mathrm{CP}$ fed in our trial. A similar pattern is commonly observed with increasing diet $\mathrm{CP}$ concentration (Kebreab et al., 2002). The proportion of urea-N in total urinary $\mathrm{N}$, which increased with elevated dietary $\mathrm{CP}$, is important because urea is the form of excretory $\mathrm{N}$ that is most rapidly degraded to ammonia and volatilized to the environment (Powell et al., 2014). Colmenero and Broderick (2006b) reported that urea increased from 55 to $82 \%$ of total urinary $\mathrm{N}$ when dietary $\mathrm{CP}$ ranged from 13.5 to $19.4 \% \mathrm{CP}$, whereas urinary urea $\mathrm{N}$ accounted for 31 to $76 \%$ to total urinary $\mathrm{N}$ in the present study when dietary CP ranged from 10.9 to $16.8 \%$ CP. A quadratic effect of dietary $\mathrm{CP}$ content on urinary urea
$\mathrm{N}$ excretion was also detected. Fecal and urinary $\mathrm{N}$ excretion were 36 and $35 \%$ of $\mathrm{N}$ intake on the $15 \% \mathrm{CP}$ diet, indicating that about $29 \%$ of dietary $\mathrm{N}$ intake was secreted as milk true protein; based on $\mathrm{N}$ intake and milk true protein secretion, apparent $\mathrm{N}$ efficiency was estimated to be about $33 \%$ on the $15 \%$ CP diet (Table 3 ). Broderick et al. (2008) observed an apparent N efficiency of $34 \%$ on a $14.8 \%$ CP diet also supplemented with RPM; however, milk and true protein yields were lower than on a RPM-supplemented diet containing 16.1\% CP. Based on theoretical computations, Dijkstra et al. (2013a) and van Vuuren and Chilibroste (2013) estimated that maximal $\mathrm{N}$ efficiency in dairy production may exceed $40 \%$.

\section{Ruminal Metabolites}

Effects of experimental diets on ruminal $\mathrm{pH}$ and mean metabolite concentrations are in Table 5. We found diet and quadratic effects on ruminal $\mathrm{pH}$, with lower $\mathrm{pH}$ values observed at intermediate dietary $\mathrm{CP}$ concentrations. We noted a trend for a quadratic effect of increasing CP content on total VFA concentration. Other major effects observed were diet and linear effects on ruminal concentrations of ammonia, total AA, and total AA plus peptides, as well as on molar proportions of isovalerate +2 -methylbutyrate and total 
Table 5. Ruminal metabolite concentrations in lactating cows fed diets with increasing CP content but with constant estimated Lys:Met ratio of 3.1

\begin{tabular}{|c|c|c|c|c|c|c|c|c|}
\hline \multirow[b]{2}{*}{ Item } & \multicolumn{4}{|c|}{ Dietary CP, \% of DM } & \multirow[b]{2}{*}{$\mathrm{SEM}^{1}$} & \multicolumn{3}{|c|}{ Probability $^{2}$} \\
\hline & 11 & 13 & 15 & 17 & & Diet & Linear & Quadratic \\
\hline$\overline{\mathrm{pH}}$ & $6.33^{\mathrm{a}}$ & $6.13^{\mathrm{b}}$ & $6.13^{\mathrm{b}}$ & $6.25^{\mathrm{ab}}$ & 0.076 & 0.03 & 0.12 & 0.01 \\
\hline Ammonia-N, mg/dL & $1.9^{\mathrm{c}}$ & $2.9^{\mathrm{bc}}$ & $4.0^{\mathrm{b}}$ & $6.1^{\mathrm{a}}$ & 0.46 & $<0.01$ & $<0.01$ & 0.16 \\
\hline TAA, $\mathrm{m} M$ & 1.6 & 2.1 & 1.9 & 2.0 & 0.15 & 0.06 & 0.02 & 0.42 \\
\hline TAA + peptides, ${ }^{3} \mathrm{~m} M$ & $3.1^{\mathrm{b}}$ & $3.9^{\mathrm{a}}$ & $3.8^{\mathrm{a}}$ & $3.8^{\mathrm{a}}$ & 0.23 & 0.03 & 0.01 & 0.28 \\
\hline Total VFA, $\mathrm{m} M$ & 85.5 & 91.8 & 93.3 & 90.2 & 3.07 & 0.22 & 0.22 & 0.10 \\
\hline \multicolumn{9}{|l|}{ Molar proportions, mol/100 mol } \\
\hline Acetate & 58.8 & 58.4 & 59.2 & 59.7 & 2.15 & 0.70 & 0.34 & 0.61 \\
\hline Propionate & 25.8 & 26.1 & 25.3 & 23.6 & 2.36 & 0.52 & 0.21 & 0.48 \\
\hline Acetate:propionate ratio & 2.37 & 2.30 & 2.41 & 2.60 & 0.319 & 0.43 & 0.19 & 0.36 \\
\hline Butyrate & 12.3 & 12.6 & 12.5 & 13.1 & 0.43 & 0.61 & 0.27 & 0.78 \\
\hline Isobutyrate & 0.89 & 0.94 & 0.89 & 0.99 & 0.045 & 0.40 & 0.26 & 0.65 \\
\hline Isovalerate +2 -methyl butyrate & $2.23^{\mathrm{b}}$ & $1.98^{\mathrm{b}}$ & $2.13^{\mathrm{b}}$ & $2.62^{\mathrm{a}}$ & 0.114 & 0.02 & 0.02 & 0.01 \\
\hline $\mathrm{BCVFA}^{4}$ & $3.13^{\mathrm{b}}$ & $2.93^{\mathrm{b}}$ & $3.03^{\mathrm{b}}$ & $3.61^{\mathrm{a}}$ & 0.121 & 0.02 & 0.02 & 0.01 \\
\hline Valerate & 2.20 & 2.47 & 2.52 & 2.29 & 0.685 & 0.85 & 0.79 & 0.43 \\
\hline
\end{tabular}

\footnotetext{
${ }^{\mathrm{a}-\mathrm{c}}$ Least squares means with different superscripts differ $(P<0.05)$.

${ }^{1}$ Standard error of the LSM.

${ }^{2}$ Probability of significant effects of dietary treatment (Diet) and linear and quadratic effects of dietary CP concentration.

${ }^{3}$ Total AA plus small oligopeptides determined using o-phthaldialdehyde-absorbance assay (see text for details).

${ }^{4}$ Branched-chain VFA (isobutyrate plus isovalerate +2 -methyl butyrate).
}

branched-chain VFA (BCVFA), which are formed from microbial catabolism of the branched-chain AA (El-Shazly, 1952). Moreover, quadratic effects were observed for molar proportions of isovalerate +2 -methylbutyrate and BCVFA. All of these compounds are produced as a result of ruminal protein degradation; their elevation in the rumen represents accumulation in excess of microbial uptake for protein synthesis and increasing concentrations with increasing dietary $\mathrm{CP}$ was anticipated.

\section{Quadratic Responses}

Regression coefficients as well as estimated maximal or minimal dietary $\mathrm{CP}$ concentrations for the variables showing quadratic responses $(P \leq 0.10)$ to dietary $\mathrm{CP}$ are in Table 6 . We observed 8 responses that had maxima ranging from 14.0 to $17.5 \%$, with a mean of $15.6 \%$. The maxima for DMI and ECM yield were both $16.2 \%$ dietary CP. Maxima for yield of milk and true protein were both above $17 \% \mathrm{CP}$, which was greater than the highest level of $\mathrm{CP}$ fed in the trial. This suggested secretion of milk and protein was not yet maximal on the diet with $16.8 \% \mathrm{CP}$ and Lys:Met ratio of 3.1. These results were similar to those of Colmenero and Broderick (2006b), who observed maxima for milk and true protein yield at, respectively, 16.7 and $17.1 \% \mathrm{CP}$ on diets composed of similar ingredients but without added RPM. All of the responses related to energy utilization (BW change, $\mathrm{OM}$ and $\mathrm{ADF}$ digestibility, and ruminal total VFA concentration) had similar maxima, ranging from 14.0 to $14.8 \%$ CP. Ruminal $\mathrm{pH}$, which would be related to ruminal OM digestibility, was minimal at $13.7 \%$ dietary CP. Molar proportions of ruminal BCVFA would be expected to be the resultant of release from protein degradation and uptake for microbial protein synthesis (Van Soest, 1994); a minimum for BCVFA was detected at $13.2 \%$ CP. Of particular interest was the quadratic response of ADF digestibility. Fiber digestion occurs primarily in the rumen (Huhtanen et al., 2010), and results from several studies have shown depressed fiber digestion on low-CP diets, possibly because of inadequate supply of RDP. Broderick (2003) reported that milk and protein yield was the same at 16.5 and $18.4 \% \mathrm{CP}$, but that $\mathrm{NDF}$ and ADF digestibility was lower at $16.5 \%$ CP. Colmenero and Broderick (2006b) observed quadratic responses to dietary $\mathrm{CP}$ concentration and a maximum for both NDF and ADF digestibility was found at $16.7 \% \mathrm{CP}$. Lee et al. (2012) were able maintain milk and protein yield on a 13.6\% CP supplemented with 3 rumen-protected AA (Met, Lys, and His), but observed depressed NDF and ADF digestibility compared with the positive control containing $15.7 \% \mathrm{CP}$. Two other traits related to $\mathrm{N}$ efficiency, MUN concentration and urinary urea excretion, had minima of, respectively, 8.0 and $6.6 \% \mathrm{CP}$. That both of these estimates were below the range of $\mathrm{CP}$ concentration fed in this trial reflected the general inverse relationship between dietary $\mathrm{CP}$ and $\mathrm{N}$ utilization often observed in feeding studies with lactating dairy cows (Huhtanen and Hristov, 2009). 
Table 6. Regression coefficients and optimal dietary CP concentrations for traits showing quadratic responses $(P \leq 0.10)$

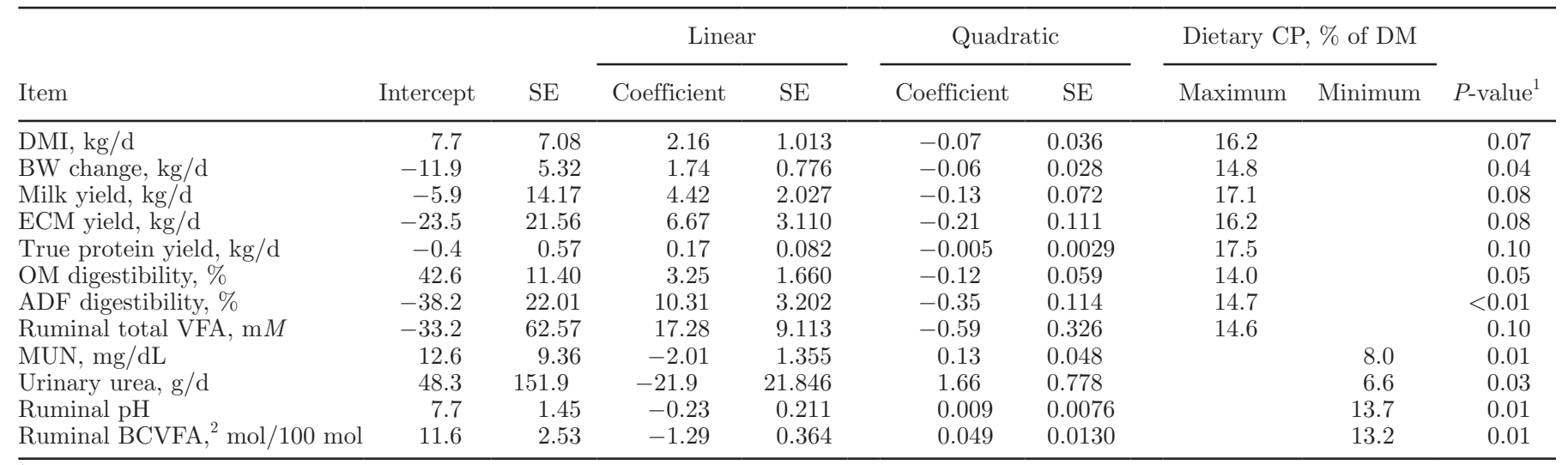

${ }^{1}$ Probability of quadratic effect of dietary CP content.

${ }^{2}$ Branched-chain VFA (isobutyrate plus isovalerate + 2-methyl butyrate).

\section{CONCLUSIONS}

A lactation trial was conducted to determine the optimal CP content of diets based on corn silage as the main forage and supplemented with SBM and RPM added to maintain a Lys:Met ratio of 3.1 in MP. Feeding the $11 \% \mathrm{CP}$ diet, in which MP was estimated to contain $2.1 \%$ Met and $6.4 \%$ Lys, depressed production. Diets containing 13 to $17 \% \mathrm{CP}$ were estimated to contain $2.2 \%$ Met and 6.8\% Lys in MP. Intake of DM and yield of milk, ECM, fat, lactose, SNF, and milk/DMI did not significantly increase above $13 \%$ CP. However, yield of true protein was lower on 13 versus $17 \% \mathrm{CP}$, but not different between 15 and $17 \%$ CP. Compared with $17 \% \mathrm{CP}$, feeding $15 \% \mathrm{CP}$ reduced MUN and N excretion and improved $\mathrm{N}$ efficiency without altering apparent total-tract DM, OM, and fiber digestibility. Overall results from this trial indicated that, with added RPM, $15 \%$ CP was adequate for lactating dairy cows producing about $40 \mathrm{~kg}$ of milk/d when fed corn silage-based diets supplemented with SBM.

\section{ACKNOWLEDGMENTS}

The authors thank Jim Meronek and his barn crew for feeding and animal care during this trial at the US Dairy Forage Research Center Farm (Prairie du Sac, WI); Wendy Radloff and Mary Becker of the US Dairy Forage Research Center (Madison, WI) for sampling and laboratory analyses; Maria Åkerlind of Växa, Uppsala, Sweden, for assisting with NorFor diet computations; and Peter Crump and Murray Clayton of the University of Wisconsin-Madison for assisting with statistical analyses. H. Nursoy gratefully acknowledges a scholarship from TUBITAK in Turkey. M. Gonzalez Ronquillo was granted funding from a Fulbright-Garcia
Robles scholarship and from the Universidad Autonoma del Estado de Mexico.

\section{REFERENCES}

AOAC. 1980. Official Methods of Analysis. 13th ed. Assoc. Off. Anal. Chem., Washington, DC.

AOAC. 1990. Official Methods of Analysis. 15th ed. Assoc. Off. Anal. Chem., Arlington, VA.

AOAC International. 1997. Official Methods of Analysis. 16th ed. AOAC Int., Arlington, VA.

Armentano, L. E., S. J. Bertics, and G. A. Ducharme. 1997. Response of lactating cows to methionine or methionine plus lysine added to high protein diets based on alfalfa and heated soybeans. J. Dairy Sci. 80:1194-1199.

Arriola Apelo, S. I., J. R. Knapp, and M. D. Hanigan. 2014. Invited review: Current representation and future trends of predicting amino acid utilization in the lactating dairy cow. J. Dairy Sci. 97:4000-4017.

Auldist, M. J., L. C. Marett, J. S. Greenwood, M. M. Wright, M. Hannah, J. L. Jacobs, and W. J. Wales. 2014. Replacing wheat with canola meal in a partial mixed ration increases the milk production of cows grazing at a restricted pasture allowance in spring. Anim. Prod. Sci. 54:869-878.

Berthiaume, R., M. C. Thivierge, R. A. Patton, P. Dubreuil, M. Stevenson, B. W. McBride, and H. Lapierre. 2006. Effect of ruminally protected methionine on splanchnic metabolism of amino acids in lactating dairy cows. J. Dairy Sci. 89:1621-1634.

Brito, A. F., and G. A. Broderick. 2007. Effects of feeding different protein supplements on milk production and nutrient utilization in dairy cows. J. Dairy Sci. 90:1816-1827.

Brito, A. F., G. A. Broderick, and S. M. Reynal. 2007. Effects of different protein supplements on omasal nutrient flow and microbial protein synthesis in lactating dairy cows. J. Dairy Sci. 90:18281841.

Broderick, G. A. 1995. Desirable characteristics of forage legumes for improving protein utilization in ruminants. J. Anim. Sci. 73:27602773.

Broderick, G. A. 2003. Effects of varying dietary protein and energy levels on the production of lactating dairy cows. J. Dairy Sci. 86:1370-1381.

Broderick, G. A., and M. K. Clayton. 1997. A statistical evaluation of animal and nutritional factors influencing concentrations of milk urea nitrogen. J. Dairy Sci. 80:2964-2971.

Broderick, G. A., A. P. Faciola, and L. E. Armentano. 2015. Replacing dietary soybean meal with canola meal improves production and efficiency of lactating dairy cows. J. Dairy Sci. 98:5672-5687. 
Broderick, G. A., M. J. Stevenson, R. A. Patton, N. E. Lobos, and J. J. Olmos Colmenero. 2008. Effect of supplementing rumen-protected methionine on production and nitrogen excretion in lactating dairy cows. J. Dairy Sci. 91:1092-1102.

Brun-Lafleur, L., L. Delaby, F. Husson, and P. Faverdin. 2010. Predicting energy $\mathrm{x}$ protein interaction on milk yield and milk composition in dairy cows. J. Dairy Sci. 93:4128-4143.

Canfield, R. W., C. J. Sniffen, and W. R. Butler. 1990. Effects of excess degradable protein on postpartum reproduction and energy balance in dairy cattle. J. Dairy Sci. 73:2342-2349.

Cerbulis, J., and H. M. Farrell Jr.. 1975. Composition of milks of dairy cattle. 1. Protein, lactose, and fat contents and distribution of protein fraction. J. Dairy Sci. 58:817-827.

Chen, Z. H., G. A. Broderick, N. D. Luchini, B. K. Sloan, and E. Devillard. 2011. Effect of feeding different sources of rumen-protected methionine on milk production and N-utilization in lactating dairy cows. J. Dairy Sci. 94:1978-1988.

Cochran, R. C., D. C. Adams, J. D. Wallace, and M. L. Galyean. 1986. Predicting digestibility of different diets with internal markers: Evaluation of four potential markers. J. Anim. Sci. 63:1476-1487.

Colmenero, J. J., and G. A. Broderick. 2006a. Effect of amount and ruminal degradability of soybean meal protein on performance of lactating dairy cows. J. Dairy Sci. 89:1635-1643.

Colmenero, J. J., and G. A. Broderick. 2006b. Effect of dietary crude protein concentration on milk production and nitrogen utilization in lactating dairy cows. J. Dairy Sci. 89:1704-1712.

Colombini, S., G. A. Broderick, and M. K. Clayton. 2011. Effect of quantifying peptide release on ruminal protein degradation determined using the inhibitor in vitro system. J. Dairy Sci. 94:19671977.

Dijkstra, J., J. France, J. L. Ellis, A. B. Strathe, E. Kebreab, and A. Bannink. 2013a. Production efficiency of ruminants: Feed, nitrogen and methane. Pages 10-25 in Sustainable Animal Agriculture, E. Kebreab, ed. CABI, Boston, MA.

Dijkstra, J., O. Oenema, J. W. Van Groenigen, J. W. Spek, A. M. van Vuuren, and A. Bannink. 2013b. Diet effects on urine composition of cattle and $\mathrm{N}_{2} \mathrm{O}$ emissions. Animal 7:292-302.

El-Shazly, K. 1952. Degradation of protein in the rumen of the sheep. 2. The action of rumen micro-organisms on amino-acids. Biochem. J. 51:647-653.

Eriksson, T., and B.-O. Rustas. 2014. Effects on milk urea concentration, urine output, and drinking water intake from incremental doses of potassium bicarbonate fed to mid-lactation dairy cows. J. Dairy Sci. 97:4471-4484.

Faciola, A. P., and G. A. Broderick. 2014. Effects of feeding lauric acid or coconut oil on ruminal protozoa numbers, fermentation pattern, digestion, omasal nutrient flow, and milk production in dairy cows. J. Dairy Sci. 97:5088-5100.

Higgs, R. J., L. E. Chase, D. A. Ross, and M. E. Van Amburgh. 2015 Updating the Cornell Net Carbohydrate and Protein System feed library and analyzing model sensitivity to feed inputs. J. Dairy Sci. 98:6340-6360

Hintz, R. W., D. R. Mertens, and K. A. Albrecht. 1996. Effects of sodium sulfite on recovery and composition of detergent fiber and lignin. J. AOAC Int. 79:16-22.

Huhtanen, P., S. Ahvenjärvi, G. A. Broderick, S. M. Reynal, and K. J. Shingfield. 2010. Quantifying ruminal digestion of organic matter and neutral detergent fiber using the omasal sampling technique in cattle-A meta-analysis. J. Dairy Sci. 93:3203-3215.

Huhtanen, P., M. Hetta, and C. Swensson. 2011. Evaluation of canola meal as a protein supplement for dairy cows: A review and a metaanalysis. Can. J. Anim. Sci. 91:529-543.

Huhtanen, P., and A. N. Hristov. 2009. A meta-analysis of the effects of dietary protein concentration and degradability on milk protein yield and milk $\mathrm{N}$ efficiency in dairy cows. J. Dairy Sci. 92:3222-3232

Huhtanen, P., K. Kaustell, and S. Jaakkola. 1994. The use of internal markers to predict total digestibility and duodenal flow of nutrients in cattle given six different diets. Anim. Feed Sci. Technol. 48:211-227.
Jordan, E. R., T. E. Chapman, D. W. Holtan, and L. V. Swanson. 1983. Relationship of dietary crude protein to composition of uterine secretions and blood in high-producing postpartum dairy cows. J. Dairy Sci. 66:1854-1862.

Kalscheur, K. F., R. L. Baldwin VI, B. P. Glenn, and R. A. Kohn. 2006. Milk production of dairy cows fed differing concentrations of rumen-degraded protein. J. Dairy Sci. 89:249-259.

Kaswari, T. 2004. Synchronization of Energy and Protein Supply in the Rumen of Dairy Cows. Cuvillier Verlag, Göttingen, Germany.

Kebreab, E., J. France, J. A. Mills, R. Allison, and J. Dijkstra. 2002. A dynamic model of $\mathrm{N}$ metabolism in the lactating dairy cow and an assessment of impact of $\mathrm{N}$ excretion on the environment. J. Anim. Sci. 80:248-259.

Krause, K. M., and D. K. Combs. 2003. Effects of forage particle size, forage source, and grain fermentability on performance and ruminal pH in midlactation cows. J. Dairy Sci. 86:1382-1397.

Kume, S., K. Nonaka, T. Oshita, T. Kozakai, and H. Hirooka. 2008 Effects of urinary excretion of nitrogen, potassium and sodium on urine volume in dairy cows. Livest. Sci. 115:28-33.

Kume, S., T. Toharmat, K. Nonaka, T. Oshita, T. Nakui, and J. H. Ternouth. 2001. Relationships between crude protein and mineral concentrations in alfalfa and value of alfalfa silage as a mineral source for periparturient cows. Anim. Feed Sci. Technol. 93:157168.

Lapierre, H., R. Berthiaume, G. Raggio, M. C. Thivierge, L. Doepel, D. Pacheco, P. Dubreuil, and G. E. Lobley. 2005. The route of absorbed nitrogen into milk protein. Anim. Sci. 80:10-22.

Lee, C., A. N. Hristov, K. S. Heyler, T. W. Cassidy, H. Lapierre, G. A. Varga, and C. Parys. 2012. Effects of metabolizable protein supply and amino acid supplementation on nitrogen utilization, milk production, and ammonia emissions from manure in dairy cows. J. Dairy Sci. 95:5253-5268.

Licitra, G., T. M. Hernandez, and P. J. Van Soest. 1996. Standardization of procedures for nitrogen fractionation of ruminant feeds. Anim. Feed Sci. Technol. 57:347-358.

Lopes, F., D. E. Cook, and D. K. Combs. 2015. Effects of varying dietary ratios of corn silage to alfalfa silage on digestion of neutral detergent fiber in lactating dairy cows. J. Dairy Sci. 98:6291-6303.

Martineau, R., D. R. Ouellet, and H. Lapierre. 2013. Feeding canola meal to dairy cows: A meta-analysis on lactational responses. J. Dairy Sci. 96:1701-1714.

McDonald, P., A. R. Henderson, and S. J. E. Heron. 1991. The Biochemistry of Silage. Chalcombe Publications, Marlow, UK.

Muck, R. E. 1987. Dry matter level effects on alfalfa silage quality. 1. Nitrogen transformations. Trans. ASAE 30:7-14.

NRC. 2001. Nutrient Requirements of Dairy Cattle. 7th rev. ed. Natl. Acad. Sci., Washington, DC.

NorFor. 2011. The Nordic Feed Evaluation System. EAAP publication no. 130, H. Volden, Ed. Wageningen Academic Publishers, the Netherlands.

Nousiainen, J., M. Rinne, and P. Huhtanen. 2009. A meta-analysis of feed digestion in dairy cows. 1. The effects of forage and concentrate factors on total diet digestibility. J. Dairy Sci. 92:5019-5030.

Nousiainen, J., K. J. Shingfield, and P. Huhtanen. 2004. Evaluation of milk urea nitrogen as a diagnostic of protein feeding. J. Dairy Sci. 87:386-398.

Overton, T. R., L. S. Emmert, and J. H. Clark. 1998. Effects of source of carbohydrate and protein and rumen-protected methionine on performance of cows. J. Dairy Sci. 81:221-228.

Patton, R. A. 2010. Effect of rumen-protected methionine on feed intake, milk production, true milk protein concentration, and true milk protein yield, and the factors that influence these effects: A meta-analysis. J. Dairy Sci. 93:2105-2118.

Powell, J. M., and G. A. Broderick. 2011. Transdisciplinary soil science research: Impacts of dairy nutrition on manure chemistry and the environment. Soil Sci. Soc. Am. J. 75:2071-2078.

Powell, J. M., C. A. Rotz, and M. A. Wattiaux. 2014. Potential use of milk urea nitrogen to abate atmospheric nitrogen emissions from Wisconsin dairy farms. J. Environ. Qual. 43:1169-1175. 
Roth, M. 1971. Fluorescence reaction of amino acids. Anal. Chem. $43: 880-882$.

Rulquin, H., and L. Delaby. 1997. Effects of the energy balance of dairy cows on lactational responses to rumen-protected methionine. J. Dairy Sci. 80:2513-2522.

SAS Institute Inc. 2013. 9.4-Guide to Software Updates. SAS Inst. Inc., Cary, NC.

Schmidt, J., P. Sipocz, E. Cenkvari, and J. Sipocz. 1999. Use of protected methionine (Mepron M 85) in cattle. Acta Vet. Hung. 47:409-418.

Schwab, C. G., R. S. Ordway, and N. L. Whitehouse. 2003. Amino acid balancing in the context of MP and RUP requirements. Pages 25-34 in Proc. Four-State Dairy Nutrition and Management Conference. Iowa State University Cooperative Extension, Ames.

Swanepoel, N., P. H. Robinson, and L. J. Erasmus. 2015. Effects of ruminally protected methionine and/or phenylalanine on performance of high producing Holstein cows fed rations with very high levels of canola meal. Anim. Feed Sci. Technol. 205:10-22.
Valadares, R. F. D., G. A. Broderick, S. C. Valadares Filho, and M. K. Clayton. 1999. Effect of replacing alfalfa silage with high moisture corn on ruminal protein synthesis estimated from excretion of total purine derivatives. J. Dairy Sci. 82:2686-2696.

Van Soest, P. J. 1994. Nutritional Ecology of the Ruminant, 2nd ed. O \& B Books Inc., Corvallis, OR.

Van Soest, P. J., J. B. Robertson, and B. A. Lewis. 1991. Methods for dietary fiber, neutral detergent fiber, and nonstarch polysaccharides in relation to animal nutrition. J. Dairy Sci. 74:3583-3597.

van Vuuren, A. M., and P. Chilibroste. 2013. Challenges in the nutrition and management of herbivores in the temperate zone. Animal 7(Suppl. 1):19-28.

Zanton, G. I., G. R. Bowman, M. Vázquez-Añón, and L. M. Rode. 2014. Meta-analysis of lactation performance in dairy cows receiving supplemental dietary methionine sources or postruminal infusion of methionine. J. Dairy Sci. 97:7085-7101. 